\title{
THE POVERTY OF INDIAN POLITICAL THEORY
}

\author{
Bhikhu Parekh*
}

Non-Western societies have frequently and rightly complained that Western political theory is ethnocentric and has a limited explanatory power when applied outside the West. One would have thought that they would therefore produce both a well-considered critique of its central categories and modes of inquiry, and an original body of ideas capable of illuminating their political experiences. Surprising as it may seem, this is not the case. No contemporary non-Western society, not even Japan, has produced much original political theory. Reasons for what I will call the underdevelopment of political theory vary from country to country. In the erstwhile Communist countries, intellectual creativity was stifled by ideological dogma and political repression. In the case of Japan such factors as the lack of a long-established tradition of political thought, the dominance of the practical impulse and the absence of serious political disagreements seem to have played an important part. In this paper I intend to concentrate on post-independence India, and to explore why a free and lively society with a rich tradition of philosophical inquiry has not thrown up much original political theory. The paper falls into three parts. In the first part I outline some of the fascinating problems thrown up by post-independence India, and in the second I show that they remain poorly theorized. In the final part I explore some of the likely explanations of this neglect.

In order to avoid misunderstanding, four points of clarification are necessary. First, by Indian political theory I mean works on political theory written by Indian writers irrespective of whether they live in India or outside it, and exclude the works of non-Indian writers on India. ${ }^{1}$

Secondly, I am primarily concerned with Indian political theory rather than with Indian political theorists. Although political theory is generally practised by political theorists, it is not their monopoly. Sociologists, historians, economists, philosophers, jurists and others too ask theoretical questions about political life. I will therefore cast my net wider and look at the works of these writers as well. It is my contention that political theory is underdeveloped among not only Indian political theorists but also their cousins in allied disciplines.

\footnotetext{
* An earlier version of this paper was presented at a senior seminar organized by the Centre for South Asia of the University of Cambridge. I am grateful to John Dunn, Geoffrey Hawthorne and John Smith for their helpful comments. I am also grateful to Bob Berki, Subrata Mitra, W.H. MorrisJones and especially Sudipta Kaviraj for their detailed comments on the paper.

${ }^{1}$ It is striking that the number of foreign political theorists interested in India, as well as the number of Indian political theorists settled abroad, is extremely small. Of the latter, very few have worked on India.
} 
Thirdly, I define the term political theory in as culturally neutral a manner as possible. For a variety of reasons too complex to discuss here, political theory has a longer history and is more developed in the West than elsewhere. However it is not absent in most other civilizations. Minimally it is concerned to offer a coherent and systematic understanding of political life, and is three-dimensional. It is conceptual in the sense that it defines, analyses and distinguishes concepts, and develops a conceptual framework capable of comprehending political life. It is also explanatory in the sense that it seeks to make sense of political life, and to explain why it is constituted and conducted in a particular manner and how its different parts are related. Finally, it is normative in the sense that it either justifies the way a society is currently constituted, or criticizes and offers a well-considered alternative to it. Since political theory understood in these terms is to be found in most major traditions of thought including the Indian, albeit in different forms and degrees, our definition is not or only minimally open to the charge of ethnocentrism or universalizing its Western form. ${ }^{2}$

Fourthly and finally, I assume that political theory is a worthwhile form of inquiry. It makes a society intelligible to itself and offers it the great gifts of self-consciousness and critical self-understanding. It thus satisfies the intellect and is intrinsically valuable. Political theory also has a practical value. It clarifies the range of choices open to a society, elucidates the limits and possibilities of political life, and explains what demands may or may not legitimately be made of it. Even when it cannot resolve disagreements, it shows what the contending parties really disagree about and how their disagreements often presuppose a shared body of understanding. Political theory analyses the terms of political discourse and brings clarity to public debate. Above all, it stands guard over the integrity of the public realm, brings critical and independent thought to bear on political life, ensures rational debate on public issues, and contributes to the creation of a civilized and healthy polity. A traditional society without serious political disagreements neither throws up nor needs political theory; in a self-conscious and reflective society, in which major institutions are inevitably subject to dispute and disagreement, political theory is a vital necessity.

\section{I}

India is the only country in the world to enshrine in its Constitution a fairly extensive programme of positive discrimination in favour of such deprived groups as the ex-untouchables and the tribals. Seats are reserved for them in parliament and in state assemblies; jobs are reserved for them in such public institutions as the civil service and the universities; and admissions are given to them on a preferential basis in professional faculties. After an interesting

2 For a further discussion see the Introduction to B. Parekh, Gandhi's Political Philosophy (London, 1989). 
debate, the Constituent Assembly of India accepted positive discrimination on the grounds that it was necessary to integrate deprived groups into the mainstream of political life, to remove the handicaps resulting from their centuries of neglect and oppression, and to break down the social barriers imposed by caste-conscious Hindus. The Indian Constitution imposed a fifteen-year limit on the programme of positive discrimination, by which time the deprived sections were expected to be able to compete with the rest on equal terms. Not only has the programme been continued for the past four decades, but it has also been extended to other socially and economically backward groups. It has more or less become a permanent tool of government policy, which no political party dare challenge without alienating the poor and deprived.

The policy of positive discrimination, especially one as extensive as the Indian, obviously raises important questions about the nature of justice, the trade-off between justice and such other equally desirable values as efficiency, social harmony and collective welfare, and the propriety of making social groups bearers of rights and obligations. It also raises questions about the nature and basis of inter-generational obligations, the redistributive role of the state, the nature and extent of the present generation's responsibility for the misdeeds of its predecessors, and the meaning and nature of social oppression. In the traditional Western and even Indian thought, justice is generally defined in terms of what is due to an individual on the basis of his qualifications and efforts. It is an individualist concept and is tied up with the ideas of agency, merit and responsibility. If social groups are to be made subjects of justice-based rights and obligations, the concept of justice must obviously be redefined in nonindividualist terms. Agency and responsibility must be conceptualized in social and historical terms, so that we can demonstrate continuity between the past and present oppressors and oppressed. We must also analyse the nature of current deprivation and show that it is a product of past oppression and confers moral claims on the oppressed. These questions become particularly important in India where the idea of positive discrimination has no roots in the indigenous cultural tradition and is much resented.

In the United States where positive discrimination has been introduced on a limited scale, considerable work has been done on these and related questions. In India where it is one of the central tools of government policy and an alien import, and where therefore one would expect considerable theoretical literature, the important questions raised by it have received little attention. ${ }^{3}$ It is difficult to think of a single legal or political theorist who has produced a major work on the subject either challenging or articulating the theory of justice lying at its basis. Some work has been done by sociologists, but most of them are

\footnotetext{
${ }^{3}$ Marc Galanter's Competing Equalities: Law and the Backward Classes in India (Delhi, 1984) is the only major work on the subject, but he is not an Indian. In the aftermath of the caste violence provoked by V.P. Singh's promise to implement the Mandal report, much interesting discussion took place in India on the subject. It remains to be seen whether the public debate will find philosophical articulation.
} 
content to rely on the American literature, without appreciating that the historical relations between caste Hindus and the untouchables and tribals bear little resemblance to those between the American whites and blacks. ${ }^{4}$

The nature of the Indian state is another important area requiring investigation. Since its emergence in sixteenth-century Europe, the modern state has been conceived as a homogeneous, sovereign, centralized and territorially bounded association of individuals. It recognizes only the individuals as bearers of political rights and obligations, and enjoys undivided and unlimited authority over all those within its area of jurisdiction. The modern state represented a novel political formation without a parallel either in pre-modern Europe or anywhere else in the world. When the British half-heartedly introduced it in India, it underwent important changes, partly because of the requirements of colonial rule and partly in response to Indian traditions and social structure. While at one level the colonial state subtly restructured the long-established communities to suit its interests, at another level it 'accepted' their laws and practices and superimposed on them a minimal body of mainly criminal laws. It did not, indeed dared not, transform the wider society along the modernist lines as its counterpart had done in Europe. Unlike its European counterpart, it permitted a plurality of legal systems, shared its 'sovereignty' with largely self-governing communities, and remained both socially segmentary and transcendental.

Post-independence India only partially rationalized the colonial state and remains a complex political formation. It has an uniform body of criminal but not civil laws. Muslims continue to be governed by their own personal laws, which the state enforces but with which it does not interfere. The tribals too are governed by their separate laws, and the state has committed itself to making no changes in the practices and laws of the Christians without their explicit consent and approval. The Parsis are subject to the same civil laws as the rest of non-Muslim Indians, but the interpretation and application of the laws is in some cases left to their panchayats or community councils. Thus the ordinary civil courts will hear a Parsi divorce case, but leave it to the Parsi panchayat to decide on the machinery of reconciliation and the amount of alimony. The Indian state is thus both an association of individuals and a community of communities, recognizing both individuals and communities as bearers of rights. The criminal law recognizes only the individuals, whereas the civil law recognizes most minority communities as distinct legal subjects. This makes India a liberal democracy of a very peculiar kind.

Again, although the Indian state is federal in nature, its federalism has a distinct character. One of its constituent units, the state of Jammu and Kashmir, enjoys a privileged status. It has its own separate flag, and citizens of the rest of India are forbidden to settle or buy land in it. If a citizen of Jammu and Kashmir were to marry someone from the rest of India, he or she and their 
children would lose their rights and privileges as Kashmiri citizens, including access to free education and admission to professional faculties. If the sixtyfourth amendment to the Indian constitution had not been defeated in Rajya Sabha, the Upper House of Indian parliament, India would have been unique in the world in being a three-tier federation, realizing the idea mooted but eventually rejected during the American constitutional debate. Local bodies would have become constitutionally recognized autonomous units entitled to levy their own taxes, enjoying freedom from interference in the exercise of several crucial powers, and holding elections like the other two tiers under the supervision of the Election Commission. A considerable body of public opinion continues to press for such a federation in the name of 'true' democracy.

It is tempting to say, as many Indian and foreign commentators have said, that the Indian state is too 'deeply embedded' in society and too 'plural' and 'chaotic' to be considered a properly constituted state, and that it is not a state in the 'true' sense of the word. But such a view is obviously too superficial and ethnocentric to be satisfactory. There is no reason why we should accept that the modern Western manner of constituting the state is the only true or proper one, and deny India and other non-Western societies the right to indigenize the imported institution of the state and even to evolve their own alternative political formations. Rather than insist that the state must be autonomous and separate from society, and then set about finding ways of restoring it to the people, we might argue that it should not be separated from society in the first instance. Rather than insist that a state must have an uniform legal system, we might argue that it should be free to allow its constituent communities to retain their different laws and practices, so long as these conform to clearly laid down and widely accepted principles of justice and fairness. Thus the law might require that a divorced wife must be provided for, and leave it to different communities to decide whether the husband, his family or his community as a whole should arrange for her maintenance, so long as the arrangements are foolproof and not open to abuse or arbitrary alteration.

Again, there is no obvious reason why a federal state may not ignore the principle of abstract equality, and grant one or more of its constituent units a privileged status if the latter's history or the considerations of national interest so require. Nor is it necessary that the state must enjoy sovereign and undivided power over its subjects. If its historical circumstances so require, it might leave all or some of its constituent communities alone to run their affairs themselves provided that they do not transgress certain limits. ${ }^{5}$ It is at least arguable that once we reject the idea that the state must be constituted in a particular manner, and allow different states to develop their distinct modes of internal organization, we might be better able to deal with ethnic conflicts and secessionist movements that the dominant model of the state finds so threatening. In the ultimate analysis the state is an institution for creating an orderly and peaceful

5 The Indian experience has shown up the limitations of the traditional notion of sovereignty. It still awaits its Bodin and hopefully a Hobbes. 
collective life. It is not impossible that in a multi-communal or multi-national society, the modern state, uncompromisingly committed to the ideas of uniform laws, individualism, abstract equality and undivided legal sovereignty, might alienate minorities and provoke conflicts and secessionist movements. Instead of being an agent of order, it might become an unwitting instrument of avoidable disorder. ${ }^{6}$

Whether or not one accepts the view that the modern state can be constituted in different ways, the fact remains that the Indian state does not conform to the Western model. One might consider it defective and seek to modernize it, or one might welcome it as a tentative but imaginative attempt to indigenize the Western model and to adopt it to the country's distinct needs. In either case it raises important questions, and challenges some of the basic categories of Western political thought. It is striking that hardly any Indian political theorist has wrestled with these questions and theorized the specificity of the Indian state. J.P. Narain and other political activists have thrown up interesting ideas on the best ways of reconstituting the Indian state, but these remain utopian and poorly worked out and have not received critical examination at the hands of political theorists. ${ }^{7}$

Since the Indian state is multi-religious and was born out of the trauma of partition on religious lines, its founding fathers concluded that it must remain secular. But they remained unclear about the meaning, implications and basis of secularism. For Jawaharlal Nehru, its first Prime Minister, religion was a private matter for individual citizens and had no public or political significance. The state was to 'transcend' and cultivate studied indifference to religion. $\mathrm{He}$ discouraged his ministers and party colleagues from attending religious functions, and was deeply offended when the President of India attended a function to mark the restoration of the Somanth temple whose destruction had for centuries been seen by the Hindus as a symbol of Muslim atrocity. Since Nehru's brand of secularism was impossible in a deeply religious society, it was hardly surprising that his government found it impossible to live up to its demands. Furthermore, for obvious political reasons he had no choice but to accept the autonomy of the Muslim personal law. This not only privileged Muslims, but also gave their religion a legal and political status. He was forced to grant a similar status to other minorities. His government gave public money to religious schools, especially Muslim, which was hardly a secular policy by his own definition. Again, Nehru rightly insisted on reforming the oppressive and discriminatory Hindu personal law. Since he was himself a Hindu, and since his government mainly consisted of the Hindus, they thought that they would

${ }^{6}$ Rajni Kothari is one of the few Indian writers to explore the relevance of the modern state to India. He challenges the nation state, and not the modern state itself. See his suggestively entitled State Against Democracy (Delhi, 1988) and Footsteps into the Future (Delhi, 1974).

7 Although many Indian political activists and theorists talk freely about the modern state, hardly any of them has carefully analysed its nature and development in Europe. For J.P. Narain, see his A Plea for Reconstruction of the Indian Polity (Delhi, 1959). 
not be accused of 'interfering' with Hindu social practices. Neither he nor his colleagues fully appreciated that in reforming the Hindu law in teeth of considerable conservative opposition, the state was acting as the reformist arm of the Hindus and was not being neutral and fully secular.

Since no state can be detached from the culture of the majority community, the independent Indian state had from its very beginning a distinct Hindu ethos. The national motto satyameva jayate (truth alone wins) is Hindu in that it comes from a sacred Hindu text and rests on Hindu metaphysic. The colours of the national flag have Hindu meanings, and the national anthem is distinctly Hindu in its language, tone and underlying philosophy. The Constitution of India begins by equating India with Bharat, a term with a deep Hindu resonance. Almost all the vernacular equivalents of the English names of the institutions of government and their heads are either Sanskrit or derived from the Hindu past $^{8}$ and the system of honours conferred by the Indian state consists of Sanskrit names.

Although Nehru and his successors defined secularism as indifference to religion, the cultural reality of India quietly continued to assert itself in these and other ways. Nehru's model was abandoned during his daughter's period of office, and secularism came to be defined not as equal indifference to but as equal respect for all religions. The new definition was as vague and incoherent as the old. No one was clear about what 'respecting' religion meant and involved, and whether it implied taking account of religious views and practices. The idea of 'equal' respect for all religions in a state whose population and leadership were predominantly Hindu continued to pose the kinds of problems raised during the Nehru period. In effect the new definition was a skilful way of allowing government leaders including the Prime Minister to indulge their religious sensibilities with a clear conscience, and for all practical purposes India became a multi-religious rather than an areligious state. Over time it became legitimate to play the 'religious card' during the elections, the state became an arena for and indeed a party to religious conflicts, and secularism was all but abandoned.

No government since independence has fully explained why India should be a secular state in its current sense, and such arguments as they have offered are unimaginative, based on fear, and derived from Western history. Most leaders have argued that secularism is necessary to ensure religious tolerance and harmony. But the argument is false. A secular state is not necessarily tolerant, for example the Soviet Union during the Communist rule or France after the French Revolution. Conversely a religious state is not necessarily intolerant of or discriminatory against minority religions, for example traditional Hindu kingdoms in India, and Muslim kingdoms in the Middle East and most of the time even in India. It could also be argued that by denying religion public identity and expression, a secular state might provoke religious conflicts. The

${ }^{8}$ For a further discussion see B. Parekh, 'Nehru and the National Philosophy of India', in Economic and Political Weekly (January 1991). 
Sikh separatists, for example, have often maintained, among other things, that the secular Indian state emasculates their religious identity and denies them collective self-expression, and that they can only preserve their identity in an independent Sikh state. The argument is unconvincing but it makes an important point. Since different religions are differently structured and come to terms with the secular world in different ways and degrees, secularism inescapably impinges on them differently and cannot be wholly impartial between them. It is of course true that in a multi-religious society the state cannot afford to be identified with a particular religion. It is also true that the state is primarily concerned with the material interests of its citizens rather than with the salvation of their souls. For these and other reasons the relation between the state and religion raises acute problems in India, but they cannot be solved by importing an alien and much-misunderstood secularist model from the West developed in a very different culture during its aggressively rationalist phase.

It is striking that with such notable exceptions as T.N. Madan and Ashis Nandy, hardly any Indian social or political theorist has seriously grappled with the question of secularism. ${ }^{9}$ There are very few books analysing the term, distinguishing its various senses, elucidating the ways in which its meaning and practice have changed since independence, explaining when and how it entered the political vocabulary of India, and what model of it best suits the country. Only a few have asked if the term itself makes sense in the Indian context where the majority religion is unorganized and doctrinally eclectic, and whether it has conceptual equivalents in the vernacular languages in which ordinary Indians think about the subject. Hardly anyone has examined if Western states are secular in the sense in which Nehru and the modernists used the term, and how religion impinges on their public life both as a cultural force and in the shape of Christian democratic parties. Since Indian civilization has a deep religious core, many secular-minded Indians have felt that they cannot be truly secular unless they reject their past, and that they must choose between their past and their future. Hardly anyone has cared to show that the dilemma is unnecessary and arises from a falsely defined model of secularism.

The legitimacy of the Indian state and the grounds of political obligation too raise difficult questions. During the colonial rule Indian leaders took a complex view of their predicament. The British were 'foreigners' who had conquered India, and hence their rule lacked political legitimacy. But they had also brought modern values to India and awakened it from a 'deep historical slumber'. They were therefore a 'progressive' force and their rule had a considerable measure of historical legitimacy. For decades Indian leaders of all political persuasions acquiesced in and even welcomed the British rule. Their attitude changed after the First World War, especially after the Jallianwalla Bagh massacre when they

9 T.N. Madan, 'Secularism in its Place', The Journal of Asian Studies, no. 4 (1987), and Ashis Nandy, 'An Anti-Secular Manifesto', in Gandhi's Significance for Today, ed. John Hick and Lamont Hempel (London, 1989). See also P.C. Chatterji, Secular Values for a Secular India (Delhi, 1984). 
began to feel that the nakedly repressive and racist British rule no longer had much to commend itself. It had to be ended not so much because it was foreign as because it had lost its historical legitimacy and progressive potential. Indian leaders also had other reasons for not stressing its foreign origins. The earlier Muslim rulers too were foreign, and therefore the anti-British struggle could easily encourage, as it sometimes did, strong anti-Muslim sentiments. Indeed one could not stop with the Muslims. The light-skinned and largely high-caste Hindus of north India saw themselves as Aryans from central Asia who had invaded and settled in India, and whose victories over the natives are celebrated in classical and popular literature. Like the Muslims and the British, they too were therefore 'foreigners' with no right to rule India! This was indeed how the Dravidians in south India and even the tribals saw them. The term 'foreigner' has a very different meaning in an ethnically eclectic country lacking a sense of collective identity to that in the relatively homogenous and territorially secure modern European states.

When India became independent, the new state drew upon both theories of legitimacy. It was legitimate because it was run by Indians and based on their consent, as expressed in the Constitution which they had freely given themselves and in the post-independence elections. It was legitimate also because it was committed to leading the country along the 'historically inevitable' path of modernization initiated but later blocked by the colonial rulers. The consensual and historicist theories of legitimacy generated different perceptions and expectations of the state, and their tension has informed much post-independence political debate. For the advocates of the consensual theory, a duly elected government has a right to the obedience of its subjects; for the champions of the historicist theory, only a government modernizing the country and promoting collective well-being has such a right. For the former, the rule of law and respect for the citizens' rights and liberties are the central concerns of the government. For the historicists the modernization of the country takes precedence, and if its 'imperatives' so require, citizens' rights and the rule of law may be infringed. The tension between the two was evident even during Nehru's period of office, but it became acute in the early seventies when his daughter skilfully used it to legitimize the Emergency.

The question of political obligation is closely connected with that of legitimacy. If the Indian state is unable to protect the basic rights and guarantee the physical security of a large body of its citizens, the question arises whether they have a moral obligation to obey it. At a different level a similar difficulty arises in the case of the wretched slum-dwellers, for whom the state not only does little but to whose oppression it is at best a passive spectator and at worst an active accomplice. Such familiar grounds of political obligation as explicit or tacit consent, political participation, collective welfare, fairness and gratitude make little sense in their case. The historicist theory upon which most politicians rely, namely that poverty and wretchedness are the inevitable price of modernization, is more plausible, but it too runs into obvious difficulties. The burdens of modernization must be shared by all, not just the poor, and they must be 
shared equitably, if the moral obligation to obey the law is to apply to all Indians equally. One needs to show too that alternative models of modernization entailing less heavy or unequal burdens are not available to the country, and that the poverty and wretchedness of the millions does really promote the long-term collective interests of all rather than those of the rich and powerful alone. $^{10}$

The functions and limits of the law too raise large questions, important both in themselves and because of their implications for political obligation. Take the practice of sati banned by the British over a century and a half ago, and a couple of cases of which in recent years have aroused considerable debate. If a woman sincerely believes that she has a religious duty to die after her husband, and that she would otherwise incur divine wrath and go to hell, is the law justified in preventing her? The law must, of course, eliminate all traces of coercion and blackmail, but once it has done so, is it right to ban the practice? If it did ban it, are those involved justified in disobeying and even resisting the law on the ground that it violates their consciences and offends their deeply-held religious beliefs? Is the law being unacceptably paternalistic in telling people what they may or may not believe and what is in their best interest? This is not at all to say that the ban on sati is wrong, rather that its grounds are unclear and could be easily extended in directions the abolitionists disapprove of. Perplexing questions arise not only with regard to the system of sati but also about the state's 'interference' with such practices as the caste system and arranged marriages, both of which it disapproves of.

The question becomes particularly acute in such a multi-cultural and multireligious society as India. The law is not and can never be morally neutral. It enjoins one class of actions and prohibits another, and needs guiding principles. If it derives these principles from one culture or religion, it discriminates against the others. If it derives them from outside the constituent cultures and religions, which is what secularism entails, they might not accept the authority of that source or prefer to define it differently. Even the so-called secular or worldly interests, which are supposed to be shared by all, are defined and graded differently by different religions. The difficulty is avoided only when the principles on which the law acts are shown to be common to all the constituent religions and cultures. But such principles are rare and the state based on them is obviously not secular in the currently dominant sense. It is hardly surprising that the question of the sources of legal morality remains unresolved in India and is evaded by all manner of subterfuges, including appeals to the looselydefined national interest and the allegedly universal but essentially liberal moral principles.

There are also several other important questions thrown up by the Indian political experience. They include such questions as the ways in which Western ideas and institutions are appropriated and filtered through their indigenous 
analogues, the languages of political discourse, the deep differences between the way political discourse is conducted in English and in the regional languages, the emerging distinction between private and public in a society which refuses to separate the two, and the concept of the political in a society which has long seen it as an inseparable dimension of the social. At a different level the Indian political experience raises questions about the kinds of concepts and methods of inquiry needed to capture the authenticity of the Indian political reality, and the merits and limitations of different methodological approaches. It also raises questions about what is likely to happen when a society, which is not structured around the state and does not consider political power and authority autonomous, decides to reorganize itself on statist lines.

\section{II}

I offered above a brief and tentative list of the kinds of questions thrown up by post-independence India. Surprising as it may seem, Indian political theorists have taken only a limited interest in them.

Post-independence India has failed to throw up either a major political theorist or significant theoretical works on such subjects as social justice, the specificity of the Indian state, secularism, legitimacy, political obligation, the nature and structure of political argument, the nature of citizenship in a multi-cultural state, the nature and limits of the law, the ideal polity, and the best way to understand and theorize the Indian political reality. There is little attempt even to test the major ideas and categories of Western political theory against the Indian political experience, and to show their ethnocentric biases and limitations. Although some work is beginning to be done in some of these areas, it remains isolated and patchy. Indian political theorists often do not take each other's work seriously enough to comment on it, and the questions raised and the concepts developed by one are not generally taken up by the others. As a result there is no co-operative engagement in a shared form of inquiry, and as yet no sign of the development of an Indian tradition of political theory.

The point made above can also be made differently. We might take four major pre-independence traditions of political thought, namely Gandhism, liberalism, conservatism and socialism, and inquire if they have been enriched and developed in the light of post-independence experiences. Mahatma Gandhi was a major leader of the struggle for independence and had great influence on his contemporaries. It is difficult to think of more than a couple of postindependence books in English or in any of the Indian languages by an Indian political theorist that creatively reinterpret his thought, or subject it to a rigorous critique. Indeed there is not yet available a definitive edition of his collected works, or even authentic translations of his four major books which were all written in his native Gujarati and hurriedly and inaccurately translated into English during his lifetime. It is a relief that Anthony Pavel, an Indian political theorist settled in Canada, is at last producing a definitive edition of Gandhi's most influential work Hind Swaraj. J.P. Narain, Vinoba Bhave, Dada Dharma- 
dhikari, Kishorlal Mashruwala and a few others have no doubt done some creative work on Gandhi, but it is patchy and lacks rigour and, what is striking, none of them was an academic. What is true of Gandhi is also largely true of such other pre-independence writers as Bankim Chatterjee, Aurobindo Ghose and even Rabindranath Tagore.

During British rule India was exposed to several European traditions of thought. ${ }^{11}$ Liberalism was the first to arrive in India, although it was inevitably appropriated in a highly selective manner. Locke was read, but Hobbes was ignored. Bentham was very popular, and while his political thought was admired, his moral theory was universally rejected. John Stuart Mill's philosophy of history was admired, his views on representative government were viewed with some suspicion, and his theory of liberty was almost wholly ignored. Herbert Spencer was widely read, but largely for his philosophy of history which was frequently invoked in defence of terrorist violence. Comte and the positivists were admired in some circles, but de Tocqueville and Benjamin Constant were ignored. T.H. Green was popular, but Bernard Bosanquet was largely ignored.

Thanks to the selective assimilation of ideas derived from different liberal writers and their fusion with indigenous philosophical traditions, preindependence India developed an eclectic but fascinating and highly influential liberal tradition cultivated by such writers as Ram Mohun Roy, Dadabhai Naoroji, Ranade and Gokhale. It wrestled with several important questions, such as the nature of the state, its relation to society and individual autonomy, secularism, the role of law in reforming society, the nature of political representation, and the principles of political morality. It is difficult to think of any major post-independence work further developing the liberal tradition and reinterpreting its insights and assumptions in the light of subsequent experiences. The questions that the liberal nationalist leaders had asked have, of course, frequently come up for discussion in parliament and especially in the courts of law whose judgments provide rich material for philosophical analysis. While some legal philosophers since independence have done some interesting work, they have paid only passing attention to questions of interests to political theory. ${ }^{12}$

Like liberalism European conservatism too was selectively received. Edmund Burke was widely read and admired for his attack on Warren Hastings and his defence of the American war of independence, but neither his attack on the French Revolution nor the underlying conservative view of politics aroused much interest. Hume was read by philosophers but not by political theorists. De Maistre, Bonald and other French conservatives were almost wholly unknown. Hegel had the greatest influence and was widely read in conservative terms by

11 Systematic work on how different European traditions and ideologies arrived in India and were read and appropriated still remains to be done.

12 Upendra Baxi's work in this area is outstanding. 
Bipan Chandra Pal and Aurobindo Ghose. These two writers, along with Swami Vivekananda and Bal Gangadhar Tilak developed a fascinating and distinctly Indian brand of conservatism, influenced and stimulated by European writers but nevertheless quite original in its central ideas and concerns. Like Gandhism the conservative tradition more or less disappeared after independence, and it is difficult to think of a single writer who has sought creatively to develop it in the light of post-independence experiences.

Socialist ideas came to India largely with Marx, and it is striking that none of the pre-Marxist or non-Marxist socialist thinkers had much influence in India. Marxism came to India during the last decade of the nineteenth century and was initally found attractive because of its theory of revolution rather than its materialist interpretation of history. The establishment of the Communist Party of India in 1925 with the blessing of the Third International shifted the focus of attention to Marx's theoretical ideas. Since the Communist Party was dominated by the Soviet Union, its Marxism did not go beyond vulgar or mechanical materialism. Neither before nor after independence have the Communist Party theoreticians offered a creative and original interpretation of Marx in the light of Indian history and experiences, or produced well-worked out Marxist or even Marxian theories of Indian history, Indian society, Indian state and social change. It is striking that the Indian Communists have not thrown up a single figure comparable to Lenin, Pashukanis, Mao or even Ho Chi Minh. M.N. Roy is the only exception, but his was more a revision and eventually a rejection than an interpretation of Marx.

Marxism outside the Communist Party fared better. Released from the stifling control of the Party, it came under the influence of and borrowed freely from such diverse sources as Gandhi, classical Indian philosophy and liberalism. While it became richer and self-critical, it also became eclectic and lost its philosophical integrity. Like Hinduism it became a mish-mash of ideas lacking internal coherence and rigour. It is only during the last few years that things are beginning to change, largely under the impact of the Gramsci-inspired school of subaltern studies. Writers belonging to this school are doing excellent theoretical and empirical work, in neither of which the earlier Marxists were strong, and are generally free from political and methodological dogmas. But their work has hitherto been confined to historical studies. Although it has important implications for political theory, these remain inadequately developed. None of the subalternists has so far addressed any of the large issues sketched earlier, and it remains an open question whether their methodological assumptions and conceptual framework will enable them to make a successful transition from historiography to political theory. Partha Chatterjee's Nationalist Thought: A Derivative Discourse, the best product so far of the subalternist approach to the history of political ideas, suggests that the transition is possible but not easy. ${ }^{13}$ 
During the struggle for independence Indian writers took considerable interest in classical India and wrote about its ideas and institutions. These first attempts to recapture and offer a reasonably coherent account of a longforgotten past laid the foundations of a new and important discipline of the history of Indian ideas and institutions. It is striking that little creative work has been done in this area since independence. ${ }^{14}$ With very few exceptions there are no new books on classical Indian political thought. Kautilya's Arthasastra is the only text on which some work continues to be done, but most of it is expository and apologetic. No attempt has been made to reconstruct and produce scholarly editions of scores of ancient Hindu, Jain and Buddhist texts on politics. There are not even anthologies of selections from them. There is no attempt to reflect on the structure and assumptions of classical Indian political thought and to show how its approach differed from its counterparts elsewhere. Medieval Indian political thought is even more neglected. Only a limited amount of work has been done on the early decades of India's encounter with Britain. Even moderately accurate information is lacking on which British and European writers were widely read, how and what response they evoked. As a result the thought of nineteenth-century Indian leaders from Ram Mohun Roy onwards, on which Indian scholars have tended to concentrate, remains opaque. We do not know what bodies of ideas were available to them, what memories of classical and medieval Indian thought were still fresh, and how these leaders conceptualized their historical predicament.

Since most Indian political theorists are not theorizing their political reality nor exploring their past, we might ask what they are doing. Broadly speaking most of their work falls into three categories. First, considerable work, some fascinating but much of it repetitive, has been and is being done on specific nationalist leaders, or on the development and structure of nationalist thought in general. ${ }^{15}$ Second, some work, mostly derivative, is being done on such contemporary Western writers as Habermas, Foucault, Gramsci and the deconstructionists, or on such movements as positivism, behaviourism and postmodernism. ${ }^{16}$ It is striking that such mainstream Western political theorists as Oakeshott, Rawls, Arendt, Leo Strauss, Macpherson and Nozick are almost entirely ignored. Finally, some work, much of it tentative and exploratory, is being done on the philosophy of the social sciences, historiography and

14 One of the outstanding exceptions is U.N. Ghoshal, A History of Indian Political Theory (London, 1959). This is however an expanded version of a book first published in 1923! It was then called A History of Hindu Political Theories. The change in title is puzzling. V.P. Varma's Studies in Hindu Political Thought and its Metaphysical Foundation (Delhi, 1954) is another interesting work, though it is not a history of Indian political thought.

15 Partha Chatterjee and the subaltern school in general have done some good work in this area. V.R. Mehta and V.P. Varma have also done interesting work, especially on Gandhi and Aurobindo, but it remains largely expository. Sudipta Kaviraj's forthcoming book on Bankim is likely to break new ground.

16 Thomas Pantham, Upendra Baxi and Sudipta Kaviraj have done interesting work in this area. 
relativism. During the colonial rule the British insisted that Western forms of life and thought were universally valid and superior to their Indian counterparts. Most Indians resented such a claim then, and continue to do so today. Their response took and continues to take the form of both demonstrating the ethnocentricity of Western forms of thought and life and insisting on the possibility of an East-West dialogue as a means to mutual enrichment. Such a critical relativism is very popular in India. Relativism deflates Western pretensions and affirms the autonomy and integrity of Indian forms of thought and life. Critical relativism enables Indians both to borrow from the West with a clear conscience and to claim that they also have something to offer it in return. Since it establishes a partnership of equals, critical relativism has considerable following and is a subject of much discussion. There is as yet no major work in this area, but enough spadework has been done for one to emerge before long. ${ }^{17}$

Of the three categories of writings, the first constitutes the greatest bulk. It is not too difficult to see why this is so. The ideas of nationalist writers are still deeply inscribed in Indian political reality and offer clues to its nature and dynamics. Such work is also easier to undertake in a country where library facilities are poor, the knowledge of the classical and medieval past is limited, and where intellectual self-confidence, thanks to years of Western domination, is too low to permit bold and creative theorizing. Ancestral piety is an important virtue in India and it too plays a role. Although there are only limited pointers in this direction, it seems that the preoccupation with the recent past is beginning to generate interest both in the pre-modern past and in the general methodological problems raised by the study of the past.

\section{III}

I argued in the previous section that Indian political theorists have taken limited interest in addressing and reflecting on the large questions raised by their unique political experiences, and that they have produced little creative political theory. This calls for an explanation. As we saw there is no shortage of material. There is no shortage of talent either, as is evident in such limited work as has been done. There is also a great need and demand for political theory to help clarify the complex and frightening nature of Indian political reality. Although political theory of the analytical and argumentative kind is relatively new to India, the country has a long tradition of writing moral and political treatises, and it has now been exposed to Western political theory for at least two centuries. In the light of all this the puzzle about the causes for the underdevelopment of political theory deepens. Without pretending to offer a conclusive or even a complete explanation, I suggest that three interrelated factors might throw some light on 
the subject. They are the way political theory is taught in Indian universities, the domination of the unofficially official political philosophy to which India committed itself at independence, and the complex nature of Indian political reality and the political theorist's inescapably ambiguous attitude to it.

\section{Teaching Political Theory}

The institutional context in which the teaching of political theory takes place in India leaves a great deal to be desired. As one would expect in a poor country the social sciences do not generally attract the ablest students, who tend to gravitate towards the professional faculties and the civil service. Futhermore, as a recently published report based on a survey of politics teaching in seventy out of the country's one hundred and fifty universities points out, a large body of politics students have an inadequate command of English. ${ }^{18}$ They have difficulty coping with books written in English by Indian authors; as for those published abroad, they are simply 'not . . . intelligible to the bulk of our students'. Most students rely on literature written in regional languages, which is generally so poor that it "cannot be recommended or recommended only at [our] peril'. ${ }^{19}$ In the absence of a comprehensive programme to translate major texts of Western political theory and the secondary Western literature into Indian languages, a programme of the kind that the Japanese embarked upon, these works remain inaccessible to Indian students. For lack of financial resources, reliable bilingual translators and academic vision, as well as because Indians are supposed to 'know' English, such a programme has often been mooted but never executed. Even those Indian students who are fluent in English generally start learning it at the age of ten or even later. Their conceptual development therefore would either have taken place in their mother-tongue, so that they think in one language and write in another with all the attendant difficulties, or it would have occurred partly in one language and partly in another, in which case their process of thinking suffers from internal dissonance and incoherence. In either case they find sustained and creative abstract thought extremely difficult, especially in English and when it comes to writing. As anyone who has taught in Indian universities knows, students with oral fluency often produce wooden, verbose and almost incomprehensible written material, and those producing highly imaginative and thoughtful essays in their mother tongue slip into clichés when speaking or writing in English. Such handicaps can and are overcome after years of hard work, training and encouragement, but inevitably only a small minority succeeds. ${ }^{20}$ The majority of the inadequately equipped students set the tone of the institution. They insist that the

18 Report on the Curriculm Development Centre in Political Science (Delhi, 1991). I thank Professor A.P. Rana for sending me a copy.

19 Ibid., pp. 776, 777.

${ }^{20}$ I say this as someone who taught at the 'English-medium' MS University of Baroda in 1957-9 and returned to it as its Vice-Chancellor in 1981-4. 
courses should not be 'too demanding', that the examinations should be 'easy', that the teachers should 'simplify' their material, and so forth. The talented students are rarely stretched and challenged, and feel frustrated.

Many a teacher of politics is recruited from such mediocre students. They have difficulty coping with primary and even secondary sources in English and seek all manner of short-cuts, including relying on superficial cribs called 'guides', consisting of simple questions and even simpler answers. Most of them publish little. There is some pressure on them to publish these days, but it does not serve its intended purpose. Articles in many a professional journal are rarely refereed and, when they are, a skilfully cultivated network of contacts influences the decision. Many publishers accept manuscripts without independent assessments. Several reputable publishers have changed the practice in recent years, and that is beginning to make a difference, but many more backstreet publishers continue to publish anything for money.

Talented Indians do, of course, produce first-rate works. But they are subject to all kinds of temptation which only a few manage to resist. Once a scholar gains recognition, he or she is often content to live on his or her laurels and stops writing. Or they become academic administrators, presiding over a system of patronage and ensuring that no one likely to outshine them gets official support and recognition. Or they get sucked into the international network of Third World scholars assiduously cultivated by the West, and assuage Western conscience by acting as its loyal and generally well-paid critics. In these and other ways talented Indians are often lost to the academic world, available neither to their students nor to their younger colleagues and setting bad examples to both. Thanks to the frustrating and bureaucratic academic climate, and to the widely noticed sense of colonial inferiority, Indian scholars tend to look to the West for recognition and approval, and they can obviously secure it only by writing on themes acceptable to the Western intellectual establishment. There is a rarely articulated but nonetheless unmistakable Western view of what 'serious' Third World scholars should think and write about, how they should study Western or their own societies, along what lines they may criticize either, and so on. The view is propagated through familiar channels, and well-tuned Indian scholars quickly pick up the message.

The way political theory is taught in most Indian universities is disappointing. According to the report mentioned earlier, all the politics departments surveyed by it offer BA (Honours) in politics requiring students to take between eight and ten papers over a period of three years. Joint degrees are rare, making it almost impossible for politics students to read philosophy, history, economics, sociology, classics or other allied disciplines. The teaching of politics, therefore, rests on a narrow basis and lacks vitalizing contacts with other disciplines. Within the Departments of Politics political theory lacks the glamour of such subjects as international relations and comparative Western politics, and does not generally attract either good students or much UGC and university patronage. As for its teaching, it is extraordinary that no department of politics seems to teach classical or medieval Indian political thought at the undergraduate or 
even at the postgraduate level. Only about a tenth of them teach even modern Indian political thought at the undergraduate level, and just over a half at the postgraduate level. The course largely concentrates on the major figures of the nationalist movement and often ignores most of post-independence thought. What is more, it centres around individuals, and neither discusses the large issues and themes raised by them nor relates their thought to post-independence experiences.

While Indian political thought remains a poor cousin, all politics departments teach Western political thought at the undergraduate level, but it too is centred around mainly modern and somewhat badly-selected individual thinkers. ${ }^{21}$ The situation is better at the postgraduate level where important concepts and problems are explored. But they are often highly general, have little relevance to India, and ignore many of the questions relating to the nature of the Indian state, political obligation, social justice, positive discrimination, violence, and the languages of Indian political discourse that were mentioned earlier. The teaching of political theory in India, as anywhere else, both reflects and reinforces the research interests of its teachers. Subjects and topics cannot be taught in the absence of a well-developed and critically tested academic literature on them, and such a literature does not get written unless there is an academic demand for it. This is true not only of political theory but also of international relations, public administration, local government, even Indian politics and the other branches of the study of politics. The kinds of criticism I have made of political theory apply to the work currently done in these areas as well.

\section{India's National Political Philosophy}

When the British rule in India became more or less firmly established in the early decades of the nineteenth century and was a pervasive and unmistakable reality, Indian leaders began to ask why their country had fallen prey to successive waves of foreign rulers of which the British were the latest. Since, unlike their predecessors, the British had not invaded India and were initially merely a trading company, the Indian self-searching acquired an added poignancy. Indian leaders wondered how they had come to such a sorry state and how they could arrest and reverse it. Various explanations were canvassed, of which what I will call modernism proved the most popular and influential.

In spite of their inevitable ambiguities and hesitations, the modernists were convinced that Indian society and civilization had been in a state of decay and decline for at least a millennium. It had become static, rigid, afraid of new ideas, inward-looking, unimaginative and repressive. India's salvation lay in making a clean break with its past and embarking upon a programme of comprehensive modernization. Not that everything in traditional India was rotten, nor that some of the traditional values and institutions might not be revived and revitalized

${ }^{21}$ In most universities they include Rawls, Habermas, Foucault, Derrida and Gramsci. 
and used as the building blocks of a new India. However, that was likely to encourage the 'spirit of revivalism' and to lead to the restoration of a good deal that was degenerate and regressive. Besides Indians were bound to disagree on which traditional values and institutions were worth revitalizing, and that was likely to distract energy and attention from the vital task in hand. In the modernist view powerful 'reactionary' and 'obscurantist' forces were constantly lurking in the background, and the deep divisions of castes, religions, sects, classes and regions that had paralysed the country for centuries were only too ready to ride on the spirit of revivalism and resist modernization. The best course of action therefore was to reject the traditional India altogether and to make a radically new start on a wholly new foundation. ${ }^{22}$

In the modernist view India must create a dynamic, open, individualist, enterprising and democratic society along modern European lines. Obviously such a task was beyond the means of its degenerate society, and the state remained the only hope. The state could undertake the task only if it was autonomous, firmly insulated against the pressures and demands of society, and was led by a Westernized élite free of traditional influences and knowledgeable about the processes of European self-transformation. Thanks to the colonial rule India already possessed such a state and élite. In the modernist view the British had learned the lessons of Indian history and created a state autonomous and independent of society. Though the colonial state was repressive, its basic design was correct and ideally suited to India. Once it was democratized and suitably reconstituted, it could become a powerful tool of national regeneration.

For a variety of reasons which we cannot consider here, the modernists won both the debate and political power. Their victory was eloquently symbolized in Gandhi's nomination of Nehru as his successor, and his conferring on him not only his enormous moral and political authority but also the historical authority of the independence movement itself. On becoming India's first prime minister, Nehru declared his total commitment to comprehensive modernization. What was even more important, he called it India's new 'national philosophy' or 'national ideology', which was 'settled once and for all' and to which the country was 'irrevocably' committed. In his view it was India's 'only hope' and 'last chance' to turn the corner, and any form of tampering with it was bound to prove 'disastrous'. For Nehru modernization involved the seven more-or-less clearly defined 'national goals' of parliamentary democracy, national unity, large-scale industrialization, socialism, secularism, nonalignment, and the development of the scientific temper. For seventeen long years he threw his great personal and political authority behind the "national philosophy', used his three election victories as evidence of popular commitment to it, ridiculed, abused and attacked those daring to challenge it, and created in the country a deep fear of disintegration should it ever waver in its commitment. While he and the other modernists felt confident that they were beginning to 
change the 'national mind', they were also acutely aware of the long distance still remaining to be covered. Caste and communal conflicts, battles surrounding the Hindu Code Bill, demands for the linguistic reorganization of the country, anti-cow slaughter agitation, and so on were all seen as evidence of the powerful 'reactionary' and obscurantist' forces nestling in the Indian soul. Every such movement made the modernists nervous and intensified their fears for the country's ability to survive as a cohesive and progressive polity. Rather than understand and enter into an open-minded dialogue with these movements, they redoubled their attacks on them and asserted the 'national philosophy' with yet greater vehemence. Their fear of the traditional Indian society and of their 'manipulable' and 'easily excitable' countrymen was so intense that they were simply not prepared to trust anyone who did not speak the standard language of the Westernized élite in an approved accent.

Since independence, then, India has had an unofficially official political philosophy. It has become so deeply embedded in national self-consciousness that even those feeling uneasy about some aspects of it rarely express their doubts, or do so in muted and hesitant tones. Since they often share the modernist analysis of the causes of Indian decline, they feel deeply worried lest they should unwittingly send the country back to its now notorious historical slumber or strengthen its regressive tendencies. The national political philosophy has also so profoundly structured the political discourse that its critics lack an adequate vocabulary in which to articulate their doubts and criticisms, let alone develop coherent alternatives. If someone is against secularism, he must be for Hindu raj; if against socialism, he must be for unbridled capitalism; if against the scientific temper, he must be for religious obscurantism; and so on.

It is hardly surprising that the range of political issues on which critical discussion is welcome in India is small, and on each the spectrum of respectable positions is considerably narrow. There is a good deal of official and unofficial pressure not to ask certain questions and not to say certain things, and hence there is much concomitant intellectual and moral self-repression. ${ }^{23}$ As a result there is little conceptual and psychological space for a critical political philoso-

${ }^{23}$ I have had two recent experiences which confirm this. I recently wrote an article published in The Times Higher Educational Supplement, large parts of which were reproduced in The Times of India. In these excerpts I argued that castes had done much damage to India and remarked that my brothers and I had married outside our caste, but wondered if the latter does not have some resources which could be utilized for progressive purposes and which explain their continuing appeal to the Indian masses. The article not only provoked critical letters, but also at least three articles in regional languages psycho-analysing me and purporting to explain why a 'Leftwing' academic had gone soft on traditional India!

A few weeks later I had a long letter published in the British newspaper The Guardian. I argued that although the so-called Hindu fundamentalism was logically incoherent, and did India much political harm, it served the historical purpose of bringing the Hindu search for identity into the open and subjecting it to the moderating discipline of political life. Fifteen eminent Indians in Britain and in India apparently thought my letter so dangerous that they wrote a collective reply wondering how a 'Gandhi scholar' could write such a letter and accusing me of presenting the BJP and Hindu fundamentalism 'with sympathy'. When I wrote back asking if this was not the same kind of intolerance of which they had accused the Hindu fundamentalists and how they hoped to cope with 
phy to grow. When neither the national political philosophy nor its dominant interpretation may be questioned, political philosophy has little role. It might be argued that it could at least be engaged in offering a well-considered philosophical defence of the national political philosophy. But this is to misunderstand the nature and role of political philosophy. When there is no criticism there is no need for justification either. Furthermore justification is necessary when what is to be justified is believed to be problematic and in need of defence. Since India's national political philosophy is largely accepted as 'obviously true', it is assumed to need no defence. Justification is also an extremely risky enterprise. It puts the national philosophy on the public agenda and opens it up to a critical debate, and there is no saying what the outcome of the debate would be or what emotions it might stir up. The safest and most effective way to 'justify' anything is not to seek to justify it at all. Political theorists in India therefore have little to do. Unless they feel intellectually and morally confident enough to deconstruct the national political philosophy and the mode of discourse generated by it, even if only to put it together in more or less its present form, they cannot produce serious political philosophy. They cannot acquire the necessary confidence unless there is a widespread questioning of the whole or parts of the national philosophy. As Marx observed, the intellect dare not imagine a realistic alternative unless the world of praxis creates a space for it.

Some popular questioning has occurred from time to time, and such creative political theory as post-independence India has produced has largely been a response to it. The modernist conception of national unity was questioned when the linguistic reorganization of the country, initially dismissed as subversive and reactionary, turned out to have beneficial consequences. Political theorists and leaders began to wonder if the cause of national unity was not best served by strong and self-confident regional units, and whether the Indian state should not be conceived as a whole made up of wholes. ${ }^{24} \mathrm{~A}$ similar change occurred when the Indian state was widely perceived to have become distant, abstract, bureaucratic, unable to command the emotional loyalty of its citizens, and when the gains of the well-meaning developmental programmes were cornered by the middlemen. The idea of Panchayati raj or local self-government, long feared by the modernists as the root of India's traditional 'spirit of localism' and fragmentation, became popular, and the dominant model of centralized parliamentary democracy was appropriately modified. ${ }^{25}$ Indira Gandhi's imposition of Emergency in 1975-7 led to a further debate on the likely pathology of the modernist conception of the state and the vital importance of non-statal forms of political organization and action. In recent years secularism, the most

the BJP, I received no reply. The net result of the debate on the caste article and on the Guardian letter was that I lost a few friends and was seen in some circles as giving respectability to 'dangerous' and 'subversive' elements. I gather from several friends that after similar experiences they resolved never to write on 'controversial' matters.

24 V.P. Verma's and Rajni Kothari's work reflect these concerns.

25 Rajni Kothari and V.R. Mehta's works deal with these themes. 
delicate item in the national political philosophy, has been put on the public agenda. Both the modernists and the Bharatiya Janata Party are agreed that it is alien to India, but they draw opposite conclusions. The former are determined to hold on to the fragile import at all costs; the latter are equally determined to discard it for that very reason. The debate has only just begun in an extremely nervous mood. If the earlier experiences are any guide, it is likely that both parties will reassess their readings of traditional India and arrive at a more indigenous model of secularism. In short every political crisis in the history of post-independence India created both the space and the need for a critical reconsideration of the national political philosophy. Its successful resolution, and the concomitant loosening of the national philosophy, liberated the country's political imagination, removed the pall of fear, and gave its theorists the confidence and the will to dare conceive and experiment with alternatives. ${ }^{26}$

\section{Indian Political Reality}

Another factor that may partly explain the underdevelopment of Indian political theory has to do with the enormous complexity and fluidity of the Indian political reality and the political theorist's deeply ambiguous relation to it. India is in a state of transition, moving from a sociocentric, loosely structured and rural society to one that is centred around and structured by the state and embarked upon a path of industrialization. The process began under the colonial rule, when India was for the first time in its history exposed to the institution of the state acting as an autonomous, independent and reformist institution. Predictably this generated much debate not only about the nature and role of the state and its relation to society, but also about the need for new forms of inquiry suited to understanding the new mode of social reconstitution. Traditional social theory, which had largely concentrated on the social structure and seen government as one of its many institutions, began to be replaced by political theory taking the state as its starting point and understanding society in relation to it. As the state became the centre of society, conditions were created for the emergence of political theory in the modern Western sense. Once the process of social change gathered pace and momentum after independence, and the state acquired unprecedented power and importance, questions not hitherto asked or asked incidentally were found unavoidable or urgent, and the stage was set for political theory to come into its own. Traditional Indian political theory was grounded in a moral consensus about the nature of the social structure and its members' duties, and had limited argumentative and critical resources. It now had to be radically transformed to cope with a vastly different social reality. New India could not be theorized in the traditional manner.

Tradition and modernity are locked in Indian society in a fascinating relationship of partnership and combat, sometimes reinforcing, sometimes correct-

${ }^{26}$ For a good discussion see V.R. Mehta, 'Political Science in India: In Search of an Identity', Government \& Opposition, Vol. 22, no. 3 (1987). 
ing and modifying, and sometimes fighting and defeating each other, and in the process redefining themselves and their relationship. Nothing has a clear and recognizable shape; nothing stands still long enough to permit careful and patient investigation; and nothing is distinct and separate enough to be studied in its own terms and without getting confused with something else. When everything is on the way to becoming something else, one is not entirely clear what concepts to use, what questions to ask, and how to go about answering them. Does India have a state? Yes and no: yes, because the Indian state has all the conventional characteristics of one; no, because it lacks a distinct ethos and moral code and has been used by several post-Nehru governments as a kind of personal fiefdom. Does India have political parties? Yes, because there are organized groups of men and women with political programmes seeking to capture political power; no, because most of these groups lack internal discipline, are united in terms of their loyalty to the leader rather than their commitment to the programme, and are willing to change their party if offered the right price. One could ask such questions about almost every aspect of political life, and the answers in each case are ambiguous.

The Indian political reality, further, is a product of different historical influences. There is the old Hindu India, itself a product of several different influences, still full of life, and increasingly being rediscovered by a society that had for centuries lost intimate contact with its past. The Muslim rule made a deep impact on the Hindu India, and so did the British. Thanks to these and other influences, felt differently in different parts of the country and in different areas of life, India lives in different historical times and contains several undigested and unassimilated chunks of different civilizations. One cannot make sense of it, let alone theorize it, unless one is reasonably familiar with the sources of the influences that have shaped it and still contain clues to its current profile. Unlike Western societies today, which have relatively stable structures and can at least up to a point be understood atemporally and in their own terms, India can only be understood in terms of its history. Time is a far greater political reality in India than in the West, requiring an Indian political theorist to master the history not only of his own society but also of those who shaped it. Thanks to colonialism and the 'modernist' educational policy of post-independence India, very few political theorists have had classical education or know Sanskrit. Unlike such Western theorists as Bodin, Hobbes and Locke who theorized the emerging European state, Indian political theorists have no direct access to their history and its idioms. They therefore cannot fully understand either their present or their past, and are constantly surprised by the behaviour of their countrymen.

As if these demands were not onerous enough, the Indian political theorist must also be a keen student of Western political theory. Political theory in the West has had a continuous history and is better developed than anywhere else. Although the Indian political theorist sometimes pretends otherwise, his traditional theoretical resources are exiguous and of limited relevance to the kinds of questions he needs to ask and answer today. He cannot learn the craft 
of political theory and acquire the necessary skills and sensibilities without mastering the tools of Western political thought. But having done so he must return to his own society, master its forms of thought, and readjust the tools to suit its distinct character. The West can help him understand what it is to do political theory; his own society can help him decide what kind of political theory to do. To master one tradition is difficult enough; to acquire an adequate command of two is beyond the reach of most. The Indian political theorist needs to go West in order to get back to the East. This is a long way back home, but it is the only way. Not surprisingly some never leave home either physically or theoretically; some others stay West both physically and theoretically; a few do return home but only physically and continue to think West.

Many an Indian political theorist who has sought to master Western political thought has tended to concentrate on contemporary thinkers, usually of the left. Although this is an understandable reaction in men and women rightly rebelling against the self-righteous West's hegemonic pretensions, and seeking to deflate these by using the weapons provided by its own internal critics, it is fraught with dangers. Contemporary Western writers write against the background of and for an audience acquainted with the tradition of Western thought, and cannot be understood without an adequate knowledge of the latter. Besides their ideas have not yet been tested by time, and it is unlikely that the towering minds of today will be so judged a hundred years on. The best way to learn the craft of political theory is to concentrate on and wrestle with the ideas of those whose reputation has survived the wreckage of time. Furthermore, although Western thinkers of the left do have some relevance to India, their relevance is necessarily limited. They are primarily concerned to explore how a society can be changed, whereas the problem in India is to understand how it is held together as well as how it can be changed. When Western writers discuss change they do so against the background of deep stability and order, whereas the problem in India is how to preserve its fragile unity while fighting for radical changes. Deconstructionism, for example, makes much sense in a society with settled structures of discourse, but it only leads to laughable gimmickry when tried out in a society which has yet to evolve such structures. Plato, Aristotle, Hobbes, Locke, Hegel, Montesquieu, de Tocqueville and others who were theorizing emergent states and mass societies, and at a different level Arendt, Oakeshott, Rawls, Dworkin and Macpherson, have more to teach Indian political theorists than those currently fashionable.

The Indian political theorist faces yet another kind of problem. As a human being living in a society in a state of flux, he is himself a transitional being carrying all its ambiguities and contradictions in his life and thought. There is a tension at the level of thought. For example, however much he pretends otherwise, the modernist finds it difficult to believe that his tradition is rotten and beyond salvation. For his part, however conservative and patriotic he might be, the traditionalist finds it difficult to sustain his faith in his tradition in the light of India's steady decline for several centuries. Again, there is a tension between thought and practice. The modernist wants a casteless society, but a 
good part of his own life and that of those he loves is spent within the caste, and he himself uses its resources in times of need. Conversely the traditionalist lives in the modern world and likes and uses its technological, cultural, moral and other resources. There is also a tension at the level of practice. The modernist wants a strong, united and industrialized India, but he also wants to retain its relaxed, gentle and undemanding way of life. He wants a hard state and a soft society, and he knows that he cannot have both. The traditionalist faces the same difficulty from a different angle.

There is hardly any Indian political thinker whose thought and life are free from such contradictions. ${ }^{27}$ Most of them continue to write as if those traditional and modern practices and institutions to which they are rightly attached can all be happily reconciled in a wonderfully harmonious society. The more selfcritical among them know that this is a pleasant but dangerous illusion. They know that they must rise above their affections and prejudices, explore the realistic choices open to India, face the consequences of these choices, and sometimes pass death sentences on many a cherished practice, value and institution. This is not easy to do. Not surprisingly many Indian political theorists find it extremely difficult to develop coherent and realistic perspectives on their country's predicament, and without such a perspective no political theory is possible. In the absence of a carefully worked out theoretical vantage point from which to gain a secure and comprehensive view of political reality, the theorist is vulnerable to eclectic sympathies and unable systematically and rigorously to interrogate his society's experiences.

\section{IV}

In the previous section I discussed three factors responsible for the underdevelopment of Indian political theory. There are also many others, which for reasons of space I have not examined. These include such things as the colonial rupture in Indian thought, the cognitive alienation of intellectuals from their society, the great difficulty of theorizing in English a reality lived and constituted partly in vernaculars and partly in a mixture of them and English, and the practical, even utilitarian, orientation of much of the traditional Indian concept of theory. The three factors I selected above are some of the most important, and both work through and provide the nodal points for most of the rest. The three are closely related and support each other. For long, Indians were moreor-less convinced that their national political philosophy was wisely chosen and that it was the only one available to them. Since most political theorists shared that view, they neither subjected it to a critical examination nor explored an

27 V.P. Verma wants the modern Indian state to be based on dharma and Vedanta and on the ideas of integral humanism and universal brotherhood. He also wants it to be a strong military state, possessing 'atom, hydrogen and neutron bombs' and refusing to yield even an 'inch of territory' in Kashmir and on the Indo-Chinese border! See V.P. Verma, Philosophical Humanism and Contemporary India (Delhi, 1979), pp. 128 f. V.R. Mehta takes a similar view. Some other writers reveal different kinds of contradiction. 
alternative to it. Some of those who were unhappy with the national political philosophy were put off by the daunting task of theorizing their complex reality afresh. Most of those who tried found it difficult to develop realistic and coherent perspectives. All this affected the way they taught and continue to teach political theory. In the absence of the original and creative theorizing of contemporary reality, teaching and research in political theory became unimaginative and centred largely around the history of nationalist political thought and fashionable Western writers. Such teaching and research in turn produced generations of students lacking the courage and the ability to engage in creative theorizing. In this and other related ways the three factors reinforced each other.

If our explanation of the underdevelopment of Indian political theory is correct, it has a wider message. Political theory does not develop in a vacuum. It requires bold and talented minds and a love of theoretical understanding for its own sake. It also requires challenging material, intellectual self-confidence, a climate of tolerance and fearlessness, a relatively firm political reality, the theorist's ability to get a critical purchase on it, and his stable moral and emotional relationship to his environment. ${ }^{28}$ In the absence of all or most of these conditions, such a politically sensitive and existentially based form of inquiry as political theory cannot flourish. This may perhaps explain why political theory has not developed in many a Third World country, as also why it has developed in some Western countries and not others and only during certain historical periods.

Bhikhu Parekh

UNIVERSITY OF HULL

28 Rajni Kothari not only shares my view of the poverty of Indian political thought but presents an even darker picture. However he offers no coherent explanation of it. See R. Kothari, A Survey of Research in Political Science, Vol. 4: Political Thought, sponsored by Indian Council of Social Science Research (Delhi, 1986), Ch.1. 